\title{
The Contribution of Modernized Fishing Technology on the Socio-economic Status of the Takalar People of South Sulawesi in Indonesia
}

\author{
Syamsul Bakhri Gaffar ${ }^{1}$ \\ ${ }^{1}$ Department of Out of School Education (J-PLS), Faculty of Education (FIP), Universitas Negeri Makassar \\ (UNM), Indonesia \\ Correspondence: Syamsul Bakhri Gaffar, Department of Out of School Education (J-PLS), Faculty of Education \\ (FIP), Universitas Negeri Makassar (UNM), Jalan. A. P. Pettarani Makassar 90222, Indonesia. E-mail: \\ syabagaar@gmail.com
}

Received: February 20, 2015 Accepted: May 24, 2015 Online Published: June 21, 2015

doi:10.5539/jsd.v8n6p31

URL: http://dx.doi.org/10.5539/jsd.v8n6p31

\begin{abstract}
This research examined the influence of modernized technology on the Takalar fishing community of South Sulawesi in Indonesia. The researcher focused on the socio-economic changes resulting from the use of improved technology in the area. A qualitative approach was employed to establish the changes that have occurred due to the use of technology. Both primary and secondary data were used. Data analysis was carried out using a qualitative-descriptive method. The findings revealed a tremendous improvement in the socio-economic status after the fishing communities adopted modernized technology, with such changes being evident among the capital owners (punggawa) and the employees (sawi). In was further established that the economic changes include increased family incomes, improved housing conditions, ownership of fully furnished homes, and accessibility to easy means of transport means. While, social changes include the changes in labor relations, from mutual cooperation to a wage based system, change in social mobility: symbolized by ownership of houses and transport facility, ownership of fishing boats and equipment, and the shift from employee status to ownership status, changes in family structures from nuclear family to extended family system, and also a significant increase in the education levels of most families in the region.
\end{abstract}

Keywords: fishing industry, mutual cooperation, social mobility, socio-economic status, systems change, technological modernization

\section{Introduction}

The desire to modernized (Overa, 2011) the fishing industry is a dream for each and every fishing community. This has led to continous change from time to time. However, such changes have either been of positive or negative impact on the community. In other words, there people who benefited from this change and there those who have benefited 'not'. For the case of the Takalar fishing community, technology has highly affected the fishermen's living standard (i.e the captial owners have gained alot while the employeed depend on mere wages). To the capital owners have benefited while those being employed continue to see almost the same situation from time to time.

Implementation of new technology, like the motorization of fishing boats and the use of modern fishing equipment, significantly influences the socio-economic status of the fishermen. Hence, they need to be trained, particularly the traditional fishermen who use simple fishing technology, and those who fish to satisfy their daily living needs. Fishing in the sea using paddle-powered boats and simple equipment like nets and fishing rods, mostly self-made, affects the catch size and quality of the business. Notably, fishermen in this situation cannot work continuously, especially during the rainy season.

To overcome the problems facing fishermen, in the 1990s, the government tried to improve their welfare by developing a fisheries policy that promoted the utilization of modern technology (Naamin, Mathews, and Monintja, 1995). The government's efforts to improve fishermen's welfare included modernizing fishing methods through motorization and other technologies. However, few fishermen followed the program, not only because of the limitations on the government's provision of fishing technology facilities, but also because of the 
unpreparediness and low awareness among the fishermen in use of new technology. Not until 2000 did the modernization of fishing techniques gain momentum among the fishing communities.

Motorization was expected to allow fishermen to expand their fishing areas and more effectively and efficiently increase their production, ultimately improving their welfare. Technology strongly influences the ability of fishermen to cultivate open (public) space and hence get a good haul. Restated, technological modernization of fisheries is likely to improve fishermen's welfare. Technology was a key factor that influenced changes, both social and economic. As Koentjaraningrat (1992) noted, fishermen's jobs depend heavily on technology. Thus, in the context of the fishing industry, modern technology (i.e., motorized and high-capacity equipment) can potentially increase catch size and quality relative to traditional technology (i.e., simple human-powered and wind-powered boats and home-made or nature-derived nets and fishing rods), thus influencing the socio-economic situation of fishermen.

Poverty and socio-economic discrepancy thus remains a challenge for fishermen. This is in line with Mubyarto, Loekman, and Michael (1984) who have pointed out that the operationalization of motorized boats does not strongly impact the income of fishermen. The system of sharing the harvest has beeb identified as the main reason fishermen remain in poverty. This is logical because in sharing the yield within the fishing industry, fishermen with capital (the owners) get the largest share while employees (the workers) depend on small wages. The two areas were chosen based on 1) first, the existing evidence of the improved economic status of the fishermen; 2) second, the improved social status of most fishermen within the two communities. This research is based on the fact that by examining the socio-economic life of the fishing communities, a clear picture can be obtained about the social life and economic status of the fishermen within the fishing regions of South Sulawesi.

The main focus of analysis in this study was the socio-economic changes in the fishing communities brought about by the use of modern technology. In the preliminary study, it was revealed that by using motorized fishing boats, the fishermen failed to yield greater results in terms of income. However, the capital owners benefited alot compared to those they employee. However, a study by Ferse, Knittweis, Krause, Maddusila, and Glaser (2012) established that to diversify fisherfolk's livelihoods, could alleviate poverty in local fishing communities which is one of the factors experienced as a result of improved infrustracture and technology. Though this is true, it is also true that with technology there are those still living a poorly. In a prelimary study, it was revealed that the improvement the socio-economic status of the capital owners does not automatically affect the lives of the workers (fishermen). Based on this background, this study examines: 1) the socio-economic conditions of the fishing communities before and after the modernization of the fishing technology; and 2) the social changes of the fishing communities before and after the introduction of modernized fishing technology.

\section{Theoretical foundation}

\subsection{Modernization and Fisheries Technology}

The numerous modernization experts cannot agree on a definition of modernization. Economists interpret modernization in terms of growth models containing various indexes, such as indicators of economy, life standards, per-capita income etc. Political scientists analyze modernization in terms of a political process, social turbulence, and institutional relationships. Sociologists define modernization from various perspectives, though always within the framework of the evolutionary perspective covering multi-linear transitions of society, from traditional to modernity. Rogers (1983) and Abraham (1991) refer to "modernization as a process by which individuals change from the traditional way of life to more complexes, technologically advanced, and rapidly change their way of living. Lerner (1978) defines modernization as a secular unilateral trend that directs ways of life from the traditional to the modern and encouraged individuals to become participants. Meanwhile, Inkeles and David (174) defined "modernization in the sense of psychological variables that have shaped certain kind of mental characteristics of modern humans, specifically, the mental factors of modern individuals which lead to the creation of a modern society. This belief led to the application of psychological changes in every individual to have modern attitudes" (Lauer, 1993).

Technological modernization of fishing is a scientific solution to a practical problem in in improving individual welfare. In simple societies that still use simple technology, all or most of the available goods and services are distributed based on social needs. In a technologically advanced society, the improved production of goods and services is distributed based on capital capacity. Therefore, the technological modernization of fisheries was defined in terms of effective capacity or real control, meaning that the control of motorization and high-capacity fishing equipment would yield an optimal result. In other words, the utilization of technological modernization of fisheries could change and improve the welfare of fishermen communities.

In this study, the technological modernization of fisheries involves modernization of the equipment used for 
fishing in fishermen communities, including motorboats, nets, and other tools. Boats, as the main equipment used in fishing, become more effective if powered by a motor. Simple and small scale nets and other equipment for catching fish were replaced with modern and large-scale equipment.

Technological modernization of fisheries was expected to improve the welfare of fishermen. However, the findings of previous researches on motorization, as stated by Siti and Salman (1996), show that the implementation of motorization failed to yield satisfactory results because the welfare improvement was only enjoyed by the bosses (the owners of the equipment), while the working fishermen, whose only expertise and source of power was catching fish at sea, earned little and suffered welfare stagnation. Therefore, this study investigated whether or not the fishermen of Aeng Batu-Batu Village, Galesong Utara Sub-district, and Talabar Regency, who also implemented motorization (like in the previous research), experienced welfare improvement as a result of technology. The researcher believes that motorization would improve welfare, and those improvements in the welfare of the capital owners would automatically result in improvements to the welfare of workers. However, the levels of improvement would not be identical because every social group requires rules or norms, including rules for wage and salary systems. Although no written rules governed these systems, there had to be local rules, or rules based on mutual agreements, in the social group.

\subsection{Socio-Economic Changes}

Social change is complex, and can include changes in social values, social norms, behavior patterns, social organization, social institutions, societal hierarchy, power and authority, social interaction, etc. These changes could be understood if there was a comparison, which could be done by examining the condition of a society at a certain time and comparing it to the previous condition of that same society. This is in line with Abdulsyani (1994: 162) who states that changes would be visible when the old social structures and life of a society could be compared with new social structures and societal life. This was also consistent with the views of experts on classical modernization who see modernization as a historical and evolutionary process of social change affecting modern life. This process is characterized by a multidimensional phenomenon in the fields of economy, politics, and society, involving a transition from simple to more complex forms .Social change occurs through three stages: Invention, the creation and development of new ideas; Diffusion, the communication of new ideas to the social system; and Consequences, the changes in the social system that result from the adoption or rejection of innovation.

This description shows that social change might begin with the creation or emergence of something new, where that something may have been desired or may simply have developed through coincidence. When the idea had spread throughout society, the process of social change entered the second stage, diffusion. Subsequently, the third and final stage, consequence or result, occurred when the social system in question changed as a result of the acceptance or rejection of an innovation.

This condition is consistent with the phenomenon of socio-economic changes that occurred in the fishermen community in Aeng Batu-Batu Village, Galesong Utara Sub-district, Takalar Regency. The fishermen switched from fishing using simple equipment to more modern methods as a result of the spread and adoption of technological modernization of fisheries. As a result of these changes, the fishermen community switched from a subsistence economy, which aimed only to satisfy the consumption needs of daily life, to a market economy, which aimed to meet a broader range of needs, ranging from clothing and food through to such things as education. The implementation or adoption of a certain technology by a society would bring a social change that could be observed through the social behaviors of its members. The changes would be visible when the adopted technology was appropriate and adaptive, and the technology could always be modified based on the needs and capabilities of adapters. Such changes could be observed in the patterns of the social relationship slinking the society with its environment. Social changes would affect the social system, including changes in the social values, traditions, attitudes, and behaviors of the members of society. Therefore, if the changes are sufficiently significant, they can bring new life in socio-economic matters, or socio-economic changes could occur in society. The socio-economic changes used as indicators to observe the socio-economic changes affecting fishermen included income, housing condition, home furnishings, entertainment appliances, vehicle ownership, labor relationships, social mobility, number of family members, and educational level of family members.

\section{Methodology}

This study employed a qualitative approach. Sugiyono (2008) stated that qualitative study investigates the natural condition of objects where the researcher acts as the key instrument and the results emphasize specific meaning instead of generalization. The subject of this study was the fishing community of Aeng Batu-Batu Village, Galesong Utara Sub-district, Takalar Regency, with households, represented by heads of family, as the 
units of observation. The observation area contained 1216 heads of fishermen families, of whom 122 , or $10 \%$ of the total, were the primary target. This was in line with Arikunto (2006) who stated that when the research subjects are too numerous, the focus should be on a smaller sample (e.g. $10-15 \%$ or $20-25 \%$ or more of the total).The fishermen in this area were grouped into two categories, punggawa and sawi.

This study used both primary and secondary data. The primary data comprised information from informants/subjects concerning their perceptions or opinions on their socio-economic life as affected by changes in fishing activities resulting from the technological modernization of fisheries. The secondary data were gathered by recording and documenting the data from the sub-district and village administration offices.

Data collection was through: (1) observations of the socio-economic life of the fishermen community; (2) in-depth interviews of a number of informants/subjects concerning their perceptions of the changes in socio-economic life before and after the technological modernization of fisheries. The data gathered were then interpreted, before being analyzed using the descriptive qualitative method. The data were analyzed qualitatively and described through three analytical steps: data reduction, data display, and conclusion drawing/verification (Miles \& Michael, 1992: 16).

There were several steps in the data analysis. The first was data selection, in which the primary and secondary data were selected. The primary data were classified, categorized, verified, and interpreted. These processes were performed gradually based on the data or information gathered from the informants/subjects via observation, before analyzing the main data. Data selection was conducted in the field after data collection. The primary data were grouped, studied and displayed in percentage form. The next step was data reduction. In this step, the data were reduced by selecting the relevant and meaningful data, and simplifying, abstracting, and transforming raw data from the written documents and notes in the field. Data reduction was meant to focus the data by ignoring unimportant elements. The final step was testing the data validity, followed by interpretation and drawing conclusions.

\section{Findings and Discussion}

Aeng Batu-Batu Village is one of nine villages in Galesong Utara Sub-district, while Takalar Regency which is the capital covers an area of $2.17 \mathrm{~km}^{2}$.The distance between Aeng Batu-Batu Village and the sub-district capital is around $3 \mathrm{~km}$, while that between the village and the capital of Takalar Regency is around $29 \mathrm{~km}$. The borders of the village are Aeng Towa Village/Tamalate Sub-district, Makassar City in the north; Bontolanra Village in the east; Sampulungan Village in the south; and the Makassar Strait in the west. The population of the village is 5137 people, comprising 2533 men and 2640 women. This number includes 1216 family heads who work as fishermen. These family heads live in five small villages, with 186 family heads in Dusun Ujung Kassi, 289 in Dusun Taman Roya, 345 in Dusun Karama, 250 in Dusun Bonto Rita, and 346 in Dusun Jonggo Batu.

\subsection{The Socio-Economic Status of Fishing Communities before and after Fishing Technology Modernization}

The socio-economic background represents one's wealth, in which the capability to own and utilize a product is strongly influenced by individual socio-economic condition. To identify the socio-economic changes of the fishermen community at Aeng Batu-Batu Village, Galesong Utara sub-district, Takalar Regency, we compared the conditions before and after fishery technology modernization. This comparison revealed clear changes after modernization, including significant socio-economic changes. Several socio-economic changes that affected the fishermen community were described, including changes in average monthly income. These changes were quantified based on measures such as the incomes of heads of families, housing condition, and ownership of furniture, entertainment appliances, and vehicles.

Income was one of the most important indicators of public wealth, and also indicated the community's capability to fulfill its needs, particularly daily needs. Changes in income in the fishermen community could improve the welfare of family members in terms of satisfying their needs for food, clothing, and shelter. Increased incomes in the fishermen community indicated successful implementation of the technological modernization of fisheries. Among 122 informant fishermen family heads in Aeng Batu-Batu Village, Galesong Utara Sub-district, Takalar Regency, before technological modernization 44 percent had monthly incomes of less than Rp. 500,000 per month, 29 percent had incomes of Rp. 500,000-1,000,000, and 27 percent had incomes exceeding Rp. 1,000,000.After technological modernization, only 2 percent had monthly incomes below Rp. 500,000 while 42 percent had incomes exceeding Rp. 1,000,000. These numbers reflected improvements in the income of fishermen communities after technological modernization, driven by price and catch volume.

The houses of Makassar fishermen who live near the coast are commonly wooden structures on stilts with roofs of palm leaves or tin. These houses are usually divided into two parts, where the top part serves as the living 
quarters, while the bottom part (the hollow space beneath the house) serves as a garage for vehicles, and an area for storing fishing equipment and fishing products. The housing at the research site essentially shares this form. The housing condition changed between before and after fishery technological modernization, although the changes were relatively insignificant and mainly involved house type, as well as size or area. Fishermen's houses could be categorized into permanent stone houses, semi-permanent stone-and-wood houses, and temporary wooden houses. Before fishery technological modernization, 11 percent of fishermen owned permanent stone houses, 16 percent owned semi-permanent stone-and-wood houses, and 73 percent owned wooden houses. After the fishermen utilized technological modernization of fisheries, 15 percent of them owned permanent stone houses, 19 percent semi-permanent stone-and-wood houses, and 66 percent owned wooden houses. Before the technological modernization, 54 percent of fishermen heads of households owned small houses.After the technological modernization of fisheries, 30 percent of fishermen owned small houses, 23 percent owned medium houses, and 47 percent owned big houses.

The roof type of fishermen's houses displayed little change in association with the technological modernization of fisheries. Before the technological modernization, 15 percent of the houses had palm-leafed roofs and 85 percent had tin roofs, while afterwards 100 percent had tin roofs. The condition of the floor in fishermen's houses also changed. Before technological modernization, the floor comprised naked earth in 12 percent of fishermen's houses, wood/planks in 72 percent, and stone/tiles in 16 percent. After modernization floor type changed, with naked earth disappearing entirely, while wood/planks accounted for 77 percent of houses, and stone/tiles for 23 percent. Another change involved number of bedrooms. Before technological modernization, 12 percent of fishermen's houses had no bedrooms, 60 percent had 1-2 bedrooms, 18 percent had 3-4 bedrooms, and around 10 percent had more than 5 bedrooms. After technological modernization this situation changed significantly, as the percentage of houses without bedrooms fell to zero, while 48 percent had 1-2 bedrooms, 32 percent had 3-4 bedrooms, and 20 percent had more than 5 bedrooms.

The changes in housing conditions for the fishermen community in Aeng Batu-Batu Village, Galesong Utara Sub-district, Takalar Regency revealed a correlation between the technological modernization of fisheries and income changes.

Home furnishings are one of many needs of family life. The furniture/appliances used as indicators and criteria in this study were chairs/couches for guests, gas burners (stoves), and refrigerators. Of the 122 surveyed informants, before the technological modernization of fisheries, 30 percent had no couch for guests, 57 percent owned 1-2 couch sets, and 13 percent owned more than 2 couch sets. After technological modernization, the number of fishermen who did not own couches for guests was 0 percent; 83 percent owned 1-2 couch sets and 17 percent owned more than 2 couch sets. The biggest changes in terms of couch ownership occurred in the categories of 'owned no couch' and 'owned 1-2 couch sets'. Couches for guests were not a primary need of fishermen, but ownership of multiple couch sets held certain prestige.

Concerning ownership of gas burners (stoves), before the modernization of fishery technology, 72 percent of the 122 informants did not own a gas burner, while 28 percent did own a gas burner. After fishery technology modernization, the number of fishermen who owned gas burners (stoves) increased to 100 percent. Besides increased incomes, the increase in gas burner ownership among the fishermen was also caused by the government's free distribution of gas burners (stoves) to those facing economic difficulties.

Ownership of refrigerators also increased. Before the modernization of fishery technology, only 18 percent of the 122 informants owned refrigerators. After the modernization, refrigerator ownership increased to 49 percent. The increase in refrigerator ownership could be viewed as an indicator of significant income improvements.

The ownership of entertainment appliances was another measure illustrating changes in the welfare or income of fishermen communities. Entertainment appliances were not primary needs, but rather fulfilled secondary needs, because such equipment not only served as entertainment media, but also as a source of knowledge and skills. Televisions were one entertainment appliance. Television ownership in fishermen communities increased after the modernization of fishery technology. Before the modernization of fishery technology, only 41 percent of fishermen owned televisions, and after modernization this number increased to 93 percent. Unsurprisingly, the punggawa group dominated in terms of the numbers and quality of televisions owned. The increased ownership of entertainment equipment (televisions) revealed a significant improvement in fishermen's incomes.

Vehicle ownership measured ownership of four-wheeled motorized vehicles (cars), motorcycles, and bicycles. Before the modernization of fisheries technology, only 2 percent of fishermen heads of households owned four-wheeled motorized vehicles (cars), 5 percent owned motorcycles, and 4 percent owned bicycles. Those who owned vehicles (cars, motorcycles, or bicycles) all belonged to the capital owner (punggawa) group. After 
modernization, 6 percent owned four-wheeled motorized vehicles (cars), 9 percent owned motorcycles (all members of these two ownership groups were punggawa), and 22 percent owned bicycles (split between 10 percent punggawa and 12 percent sawi).Considering the increase in vehicle (car, motorcycle, or bicycle) ownership, significant change or improvement can be said to have occurred in fishermen's incomes, in both the punggawa and sawi groups.

Based on the socio-economic condition of the fishermen's community as outlined above, it can be stated that significant changes occurred after the modernization of fisheries technology, in both the punggawa and sawi groups. Previous studies on the modernization of fisheries technology in different sites found that modernization had not yet yielded satisfactory results because the punggawa were the only group that experienced improvements in income and quality of life, while the sawi experienced no such improvements (Mubyarto, Loekman, and Michael, 1984; Sitti and Salman, 1996). However, this study found a different view, that is that modernization of fisheries technology significantly improved both income and the quality of life, and the benefits were shared among both the punggawa and sawi groups. The discrepancies between income and quality of life improvements for punggawa and sawi resulted from differences in their status. Differences in status between individuals naturally cause differences in ownership and social access to self-improvement.

\subsection{Social Changes in Terms of Labor relations, Social Mobility, Numbers of Family Members, and Educational Level in the Fishing Communities}

Field observation showed that in the fishermen community at Aeng Batu-Batu Village, just as in fishermen communities elsewhere, interactions may occur among fishermen in the form of working together (mutual cooperation), wage system, and independent work. These relationships can change due to modernization of fisheries technology.

In this study, the relationships between fishermen and other parties were investigated in two activity time frames:

(1) the repair of boats and fishing equipment before fishermen went to sea and (2) the processing of the harvest (fish caught) occurred after fisherman returned from sea. Before technological modernization of fisheries, the fishermen implemented systems based on mutual cooperation and wage payment. The findings showed that of the 122 fishermen informants, 5 percent repaired their boats and equipment by themselves, 34 percent paid others to perform repairs, and 61 percent relied on mutual cooperation to perform repairs. These numbers changed after the modernization of fisheries technology, with 7 percent repairing their own boats and equipment, 70 percent paying others to perform repairs, and 23 percent relying on mutual cooperation to perform repairs. In terms of harvesting activity, before the modernization of fisheries technology, 39 percent of fishermen processed their own harvest/catch, 10 percent paid others to do it for them, and 51 percent relied on mutual cooperation for catch processing. After the fisheries underwent technological modernization, just 5 percent of the fishermen processed their own catch, 62 percent paid others to do it, and the remaining 33 percent relied on mutual cooperation.

These findings showed that after fishery modernization, mutual cooperation decreased, including in both repair work and harvest processing. Meanwhile, reliance on wage payment to ensure performance of both these tasks increased.

Based on these findings, it can be said that after the utilization of technological modernization of fisheries, a tendency existed among the fishermen to abandon mutual cooperation in favor of a wage system.

Social mobility describes the likelihood of an individual moving upward or downward in terms of status, level, or position of power. This study defined social mobility as the shift of fishermen status from sawi to punggawa, which was indicated by the ownership of property in the form of motorization and modern fishing equipment. Before fishery modernization, 83 percent of the 122 informants had sawi status and 17 percent had punggawa status. After technological modernization, the proportion holding punggawa status increased to 32 percent . This shift in status was also related to property ownership, including house condition, ownership of furniture/appliances, ownership of vehicles, and income level, as described in the discussion on socio-economic conditions before and after fishery technological modernization.

A family comprising a husband, wife, and children is called a nuclear family, while a family that comprises a husband, wife, in-laws, uncles, aunts, and other family members, is called an extended family. The family member indicator used in this study was such that it included both nuclear and extended families. The findings of this study showed that the distribution of family members before the implementation of modernized fishery technology were as follows: 6 percent of families consisted of a husband and wife; 43 percent consisted of husband, wife, and children; 30 percent consisted of a husband, wife, children, and parents-in-law; and 21 percent consisted of a husband, husband, wife, parents-in-law, children-in-law, and grand children. Following 
the modernization of fisheries technology, 0 percent of families consisted of a husband and wife; 30 percent consisted of a husband, wife, and children; 39 percent consisted of a husband, wife, children, and parents-in-law; and 31 percent consisted of a husband, wife, parents-in-law, children-in-law, and grand children. These data indicated that fishermen families became more likely to adopt an extended family structure after the modernization of fisheries technology.

The educational level of family members in fishermen communities also increased. The findings showed that family members in the fishermen community displayed varied educational levels. Before the modernization of fisheries technology, 23 percent of families either had no members that had attend school or none that had finished elementary school; 32 percent had members who had finished elementary school; 37 percent had members that had finished senior high school; and 8 percent had members that had finished a university/college education. After the modernization of fisheries technology, families became increasingly aware of the importance of formal education for family members. This was evident from the data showing that only 13 percent of families had members that did not attend or did not finish elementary school; 38 percent had members with an elementary school education; 39 percent had members with a senior high school education; and 10 percent had members with a university education. This meant that levels of educational achievement among the fishermen community changed significantly after the modernization of fishery technology.

Social changes in terms of labor relationships, social mobility, numbers of family members, and educational level appeared after the utilization of the technological modernization of fisheries .This was consistent with Abdulsyani (1994) who stated that changes would be visible when the old social structures and life of a society could be compared with the new social structures and societal life. This was also consistent with the views of classical modernization experts who saw modernization as a historical and evolutionary process of social change affecting modern life.

Based on the above findings and discussion, it could be stated that the fishermen community at Aeng Batu-Batu Village, Galesong Utara Sub-district, Takalar Regency, had experienced socio-economic changes indicated by the changes in the terms of the increase of income, better housing conditions, ownership of more home furnishings, and ownership of better vehicles and entertainment appliances. Social changes also changed through the shift from the system of mutual cooperation to that of wage payment and independent work. Social mobility also changed, mainly due to the availability of vehicles that facilitated relationships with the outside community, bigger houses that could accommodate visiting relatives and the shift from sawi to punggawa status as a result of increased incomes and knowledge of better utilization of the technological modernization of fisheries. In terms of family structure, fishermen's families tended to become extended families. The level of formal education of family members also significantly changed to reflect success in increasing the income and quality of life of fishermen families, after the modernization of fisheries technology.

\section{Conclusion}

This study was based on the assumption that the modernization of fishing technology would lead to socio-economic changes for fishermen, including both capital owners (punggawa) and workers (sawi). Based on the findings and discussion, it can be concluded that fishery technological modernization has been followed by: (1) several significant socio-economic changes in the fishermen community, including both the punggawa and sawi groups, at Aeng Batu-Batu Village, Galesong Utara Sub-district, Takalar Regency, including increased income, better housing conditions, ownership of better and more furniture, and ownership of vehicles and better entertainment appliances; and (2) social changes that included changed labor relations, from mutual cooperation to systems based on wages and independent work; altered social mobility, as evidenced in house and vehicle ownership, ownership of fishing boats and fishing equipment, and the shift from sawi to punggawa status; a change in family structure, from nuclear to extended families; and a significant increase in the educational level of family members.

\section{References}

Abraham, F. M. (1991). Modernisasi di Dunia Ketiga: Suatu Teori Umum Pembangunan. M. Rusli Karim (Penerjemah). Yogyakarta: PT. Tiara Wacana.

Abdulsyani. (1994). Sosiologi Skematika Teori dan Terapan. Jakarta: Bumi Aksara.

Arikunto, S. (2006). Prosedur Penelitian: Suatu Pendekatan Praktik. Jakarta: PT. Rineka Cipta.

Everett, M. R. (1983). Diffusion of Innovations (3rd ed.). New York: The Free Press.

Ferse, C. A. S, Knittweis, L., Krause, G., Maddusila, A., \& Glaser, M. (2012). Livelihoods of Ornamental Coral Fishermen in South Sulawesi/Indonesia. Implications for Management, Coastal Management, 40(5). 
http://dx.doi.org/10.1080/08920753.2012.694801

Inkeles, A., \& David, H. S. (1974). Becoming Modern, Individual Change in Six Developing Countries. Cambridge: Havard University Press. http://dx.doi.org/10.4159/harvard.9780674499348

Koentjaraningrat. (1992). Beberapa Pokok Antropologi Sosial. Jakarta: Dian Rakyat.

Lauer, R. H. (1993). Perspektif tentang Perubahan Sosial. Edisi II diterjemahkan oleh Alimandan. Jakarta: Rineka Cipta.

Lerner, D. (1978). Memudarnya Masyarakat Tradisional. Mul jar to Tjokrowi no to (Ed). Gajah Mada University Press.Yogyakarta.

Miles, B. M., \& Michael, A. H. (1992). Analisis Data Kualitatif. Terjemahan. Jakarta: UI Press.

Mubyarto, Loekman, S., \& Michael, D. (1984). Nelayan dan Kemiskinan. Studi Antropologi di dua Desa pantai. Jakarta: Rajawali.

Naamin, N., Mathews, C. P., \& Monintja, D. (1995). Studies of Indonesian tuna fisheries, Part I: Interaction between coastal and offshore tuna fisheries in Manado and Bitung, North Sulawesi. in Status of Interactions of Pacific Tuna Fisheries in 1995.Diakses di: http://www.fao.org/

Overa, R. (2011). Modernisation Narratives and Small-Scale Fisheries in Ghana and Zambia. Forum for Development Studies, 38(3). http://dx.doi.org/10.1080/08039410.2011.596569

Sitti, B., \& Salman, D. (1996). Kemiskinan Struktural dan Polarisasi Sosial pada Masyarakat Nelayan: Studi Efek Modernisasi Alat Tangkap terhadap Perubahan Sosial Masyarakat Nelayan di Desa Tana Lemo, Bulukumba. Ujungpandang: LP-Unhas.

Sugiyono. (2008). Memahami Penelitian Kualitatif. Bandung: Alfabeta.

\section{Copyrights}

Copyright for this article is retained by the author(s), with first publication rights granted to the journal.

This is an open-access article distributed under the terms and conditions of the Creative Commons Attribution license (http://creativecommons.org/licenses/by/3.0/). 